\title{
Helmet Use and Associated Factors among Thai Motorcyclists during Songkran Festival
}

\author{
Penprapa Siviroj ${ }^{1}$, Karl Peltzer ${ }^{2,3, *}$, Supa Pengpid ${ }^{4}$ and Sompong Morarit ${ }^{5}$ \\ 1 Department of Community Medicine, Chiang Mai University, Chiang Mai 50200, Thailand; \\ E-Mail: psiviroj@mail.med.cmu.ac.th \\ 2 HIV/AIDS/SIT/and TB (HAST), Human Sciences Research Council, Pretoria 0001, South Africa \\ 3 Department of Psychology, University of the Free State, Bloemfontein 9300, South Africa \\ 4 Department of Health System Management and Policy, University of Limpopo, Medunsa Campus, \\ Pretoria 0204, South Africa; E-Mail: supaprom@yahoo.com \\ 5 Health Promotion Region 10, Ministry of Public Health, Chiang Mai 5000, Thailand; \\ E-Mail: smorarit@gmail.com
}

*Author to whom correspondence should be addressed; E-mail: kpeltzer@hsrc.ac.za; Tel.: +27-12-302-2000; Fax: +27-12-302-2067.

Received: 4 June 2012; in revised form: 20 August 2012 / Accepted: 4 September 2012 / Published: 10 September 2012

\begin{abstract}
The aim of this study was to assess helmet use and associated factors among motorcycle riders during Songkran festival in Thailand. A cross-sectional survey was conducted to determine the prevalence of helmet use among Thai motorcycle riders (sample size $=18,998$ ) during four days of the Songkran festival. For this sample, the population of motorcycle riders was consecutively selected using quota sampling from 12 petrol stations in four provinces from each of the four main geographical regions of Thailand. The study was conducted at petrol stations at roads in town, outside town and highway at different time intervals when trained field staff administered a structured questionnaire and performed an observation checklist. Results indicate that $44.2 \%$ of the motorcycle riders and $72.5 \%$ of the motorcycle passengers had not been using a helmet. In multivariable analysis demographics, environmental factors, helmet use experiences and attitudes and recalling a lower exposure to road safety awareness (RSA) campaign were associated with non-helmet use among motorcyclists. It appears that the RSA campaign may have some positive effect on reducing non-helmet use among motorcycle riders during the Songkran festival.
\end{abstract}


Keywords: helmet use; motorcyclists; road safety awareness campaign; Thailand

\section{Introduction}

The Road Traffic Injury (RTI) fatality rate in Thailand was 40 per 100,000 population in 2007, i.e., double the world average for low- and middle-income countries [1]. In Thailand, RTIs are the second leading cause of burden of disease [2]. Motorcycle-related crashes accounted for the majority (more than $70 \%$ ) of injuries and deaths related to road traffic in Thailand [3-5]. A number of known behavioural risk factors have been identified, i.e., drunk driving, speeding, substance abuse, and failure to use helmets and seat belts [6,7]. Youth risk survey data from Bangkok show that the risk behaviours leading to traffic accidents were rarely or never having worn a helmet while motorcycling (50.1\%) [8]. Survey data from 38 provinces in Thailand in the year 2007 found that the helmet wearing rate in drivers was $54.0 \%$ and among passengers 30.9\% [9]. Other studies from low and middle income countries also found a high prevalence of non-helmet use of motorcyclists (China 34-37.4\% [10,11], India 68.6\% [12], Iran 89.3\% [13], Nigeria 76.2\% [14], Vietnam 70.1\%, [15] and generally lower among passengers (China 65.9\% [11]). Based on a literature review, it was found that factors associated with non-helmet use among motorcyclists included age (younger people) $[10,15,16]$, gender (male riders [10], female riders [11,15]), being a passenger [11], location (secondary streets [10], inner-city roads [15], outside city roads [11]), time of day (less during evening, night-time [10,16-18], weekends [10], lack of intention and perceived behavioural control [13] and having ever had a traffic accident [19].

According to the Road Traffic Act 1979, section 122, motorcyclist and passenger are obliged to wear a helmet to protect themselves from harm during driving [9]. Helmets and helmet use laws have been shown to be effective in reducing head injuries and deaths from motorcycle crashes [20]. In a study in Thailand, the probability of fatality due to head injuries was reduced by $38 \%$ for motorcyclists wearing helmets and by $43 \%$ for those riding under alcohol influence [18]. Ichikawa et al. [17] found that after enforcement of the helmet act, helmet-wearers increased five-fold while head injuries decreased by $41.4 \%$ and deaths by $20.8 \%$ in Thailand. Motorcycle rider education seemed to have had a positive effect on changes in risk behaviours and motorcycle-related injuries in rural Thailand [21].

From 1997 an active public education programme was undertaken on a national scale to raise awareness about road safety and to support law enforcement. This included dissemination of knowledge through multiple channels, e.g., roadside posters, stickers on the back of vehicles, sporadic radio and TV programmes or spots, public announcements and press reports [22]. After 2000, communication about the law was increased and both governmental and nongovernmental agencies started to participate in traffic injury prevention and control programmes including helmet wearing among motorcyclists and passengers [6,23]. This included also increased Road Safety Awareness (RSA) campaigns during the Songkran festival, but seemingly not everywhere the full range of RSA campaigns were implemented [24]. In addition, the following law enforcement strengthening activities focused on helmet-use, safe motorcycle-riding, driving licenses, and speed limiting especially during the Songkran Festival, and a “drive safely, turn head-light and wear helmet” campaign [25].

Songkran is the New Year celebration in Thailand, set by the solar calendar since ancient times. It 
takes place between 13 and 15 April. Songkran festivals are major holidays that encourage a million travellers who travel to/from their hometown and doing the activities during these holiday periods [26]. Unfortunately, the number of road accidents, fatalities and injuries increases dramatically; in April the number of road traffic fatalities was almost 1,200 persons, way above the average of less than 1,000 [26]. The daily fatalities during Songkran festival rise up to 84 and 95 persons per day, compared with an average of 34 persons per day in the non-festival period. Similarly, daily injuries during Songkran holidays in April increased to 4,900 and 5,650 persons, or 98\% and 128\% compared with an average of 2,468 persons per day during the non-festival period [27]. During Songkran holidays motorcycles were the major cause of road traffic accidents (76.7\%) [28] and the most common causes identified included alcohol use (41\%) [28,29] and not wearing a helmet (98.4\%) [28]. The aim of this study was to assess helmet use and associated factors among motorcycle riders during Songkran festival in Thailand.

\section{Methodology}

\subsection{Sample and Procedure}

A cross-sectional survey was conducted to determine the prevalence of helmet use among Thai motorcycle riders. The recruitment period of this project was during four days of the Songkran festival for 13-16 April, 2007. For this sample the population of motorcycle riders from 12 petrol stations was selected using quota sampling from four provinces from each of the four main geographical regions of Thailand excluding Bangkok. Provinces were Chiang Mai, Lampang, Nakhon Sawan and Phichit in the northern region, Nakhon Ratchasima, Khon Kaen, Udon Thani, and Loei in the northeastern region, Songkhla, Phuket, Surat Thani, and Trang in the southern region, and Phra Nakhon Si Ayutthaya, Chonburi, Chachoengsao, and Phetchaburi in the central region. In total 48 petrol stations (three petrol stations per province) were selected. In town, the petrol station on the road with the largest shopping mall was selected; out of town the petrol station on the road leading to the largest district was selected; in terms of petrol station on the highway, each province only has one highway. If there was more than one petrol station on the selected road or highway, the largest petrol station was selected. The study team spent four days at each petrol station road venue (roads in town, outside town and highway) for 7:00-9:00, 13:00-15:00, 17:00-19:00, and 22:00-24:00.

All consecutive motorcycle riders who entered the petrol station were asked to participate by trained personnel (who were students from Chiang Mai University that were trained by the research team) while they were having their gas tank filled. The number of vehicles and time interval for vehicle selection were determined by the availability of field staff to conduct a motorcycle rider observation, interview and alcohol test. The target sample size was 100 motorcycle riders from each of the petrol stations per time period, except during 22:00-24:00 for which 50 motorcycle riders were targeted. Trained field staff administered a structured questionnaire and performed an observation checklist. The project was approved by the Ethics Committee for research in human subjects of the public health programme, Chiang Mai University. 


\subsection{Measures}

The primary outcome of the study was helmet use. Helmet use was assessed by observation. The questionnaire covered demographic data, motorcycle characteristics, history of road traffic accidents, known risk factors such as age, sex, environmental factors, helmet use experiences and attitudes, and exposure to road safety awareness (RSA) campaign.

\subsection{Data Analysis}

Data were analyzed using Statistical Package for the Social Sciences (SPSS) for Windows software application programme version 19.0. Frequencies, means, and standard deviations were calculated to describe the sample. Data were checked for normality distribution and outliers. Interaction between predictor variables was also examined and it was found that none of the variables had a Variance Inflation Factor (VIF) value above 2.5. Associations of non-helmet use were identified using logistic regression analyses. A multivariable regression model was constructed. Independent variables (demographics, environmental factors, helmet use experiences and attitudes and exposure to road safety awareness campaign) from the univariate analyses were entered into the multivariable model if significant at $P<0.05$ level. For the model, the $\mathrm{R}^{2}$ is presented to describe the amount of variance explained by the multivariable model. Probability below 0.05 was regarded as statistically significant.

\section{Results and Discussion}

\subsection{Sample Characteristics}

The sample included 18,998 motorcycle riders (67.3\% male and 32.7\% female) of whom 320 refused to participate, giving a response rate of $98.3 \%$. Overall, $44.2 \%$ of the motorcycle riders had not been using a helmet. Almost half of the motorcycle riders (49.6\%) had a passenger (60.2\% female and $39.8 \%$ male) of which $72.5 \%$ had not been wearing a helmet. The largest group of the motorcycle riders were between 18 to 25 years old (43.9\%), followed by 26 to 59 years olds (41.8\%), 2.2\% were below the legal motorcycle riding age $(<15$ years), and among those who were 15 to 17 years old $46.1 \%$ were illegally riding a size of motorcycle with more 110 cc. The data collection was equally distributed across four regions, four days of data collection; three locations of data collection and data collection across three different times during the day, only data collection in the evening yielded a smaller sample (see Table 1).

\subsection{Helmet Use Experiences, Attitudes and Road Safety Awareness Campaign Exposure}

About one third of the motorcycle riders (33.4\%) indicated that they had been in an accident before, mostly as a rider (75.5\%), followed by passenger (22.8\%) and pedestrian (1.5\%). Almost half had had the intention to use a helmet (44.8\%). A large group agreed with the danger of non-helmet use (75.0\%) and almost two-thirds were highly aware of the danger of not using a helmet (55.8\%). Almost half (47.2\%) had been caught with the non-use of a helmet before.

The majority (83.9\%) had heard about an RSA campaign, 29.2\% had frequently heard or seen the RSA campaign on the radio and/or TV, and 29.3\% frequently followed TV news reports on road traffic 
injury (RTI) statistics. Two in five (40.1\%) had also been talking to others about the RSA campaign and most (89.0\%) liked the RSA campaign (see Table 2).

Table 1. Demographic, motorcycle and environmental sample characteristics of motorcyclists (during Songkran festival) $(\mathrm{N}=18,998)$.

\begin{tabular}{|c|c|c|c|c|}
\hline & \multicolumn{2}{|c|}{ Total } & \multicolumn{2}{|c|}{ Non-helmet use of rider } \\
\hline & Number & $\%$ & Number & $\%$ \\
\hline \multicolumn{5}{|c|}{ Demographics } \\
\hline All & 18,998 & & 8,369 & 44.2 \\
\hline Male & 12,744 & 67.3 & 5,683 & 44.7 \\
\hline Female & 6,183 & 32.7 & 2,651 & 43.0 \\
\hline \multicolumn{5}{|l|}{ Age (by self-report) } \\
\hline$<15$ & 403 & 2.2 & 203 & 50.6 \\
\hline $15-17$ & 2,045 & 11.4 & 1,245 & 61.1 \\
\hline $18-25$ & 7,860 & 43.9 & 3,895 & 49.7 \\
\hline $26-59$ & 7,480 & 41.8 & 2,449 & 32.8 \\
\hline 60 or more & 128 & 0.7 & 39 & 31.0 \\
\hline \multicolumn{5}{|l|}{ Region } \\
\hline North & 4,546 & 23.9 & 2,850 & 62.9 \\
\hline Central & 4,663 & 24.5 & 2,003 & 43.1 \\
\hline Northeast & 4,989 & 26.3 & 2,135 & 43.1 \\
\hline South & 4,800 & 25.3 & 1,381 & 28.8 \\
\hline \multicolumn{5}{|c|}{ Motorcycle and environmental characteristics } \\
\hline Type of motorcycle & & & & \\
\hline $50-110$ сс & 7,047 & 31.1 & 3,179 & 45.2 \\
\hline Over 110 cc & 5,910 & 37.1 & 2,717 & 46.1 \\
\hline Missing & 6,041 & 31.8 & & \\
\hline Data collection time & & & & \\
\hline 07:00-09:00 & 5,557 & 29.3 & 2,308 & 41.7 \\
\hline 13:00-15:00 & 5,790 & 30.5 & 2,619 & 45.4 \\
\hline 17:00-19:00 & 5,688 & 30.0 & 2,524 & 44.5 \\
\hline 22:00-24:00 & 1,943 & 10.2 & 910 & 47.1 \\
\hline Date of data collection & & & & \\
\hline 13 April 2007 & 4,910 & 25.8 & 2,313 & 47.3 \\
\hline 14 April & 4,616 & 24.3 & 2,068 & 44.9 \\
\hline 15 April & 4,744 & 25.0 & 2,217 & 47.0 \\
\hline 16 April 2007 & 4,726 & 24.9 & 1,770 & 37.6 \\
\hline Location of data collection & & & & \\
\hline Main road in town & 6,306 & 33.2 & 2,663 & 42.4 \\
\hline Roads out of town & 6,265 & 33.0 & 2,872 & 46.1 \\
\hline Highway & 6,406 & 33.8 & 2,815 & 44.2 \\
\hline
\end{tabular}


Table 2. Helmet use experiences and attitudes and exposure to road safety awareness campaign of motorcyclists (during Songkran festival) $(\mathrm{N}=18,998)$.

\begin{tabular}{|c|c|c|c|c|c|}
\hline \multirow[t]{2}{*}{ Variable } & \multirow{2}{*}{$\begin{array}{l}\text { Response } \\
\text { options }\end{array}$} & \multicolumn{2}{|c|}{$\begin{array}{l}\text { Total motorcycle } \\
\text { riders }\end{array}$} & \multicolumn{2}{|c|}{ Non-helmet user } \\
\hline & & Number & $\%$ & Number & $\%$ \\
\hline \multicolumn{6}{|c|}{ Helmet use experiences and attitudes } \\
\hline \multirow[t]{2}{*}{ Been in accident before } & No & 12,649 & 66.6 & 5,479 & 43.5 \\
\hline & Yes & 6,349 & 33.4 & 2,890 & 45.7 \\
\hline \multirow[t]{3}{*}{ Rider status when in accident } & Rider & 4,557 & 75.7 & 2,146 & 47.2 \\
\hline & Passenger & 1,370 & 22.8 & 601 & 44.1 \\
\hline & Pedestrian & 93 & 1.5 & 37 & 39.8 \\
\hline \multirow[t]{2}{*}{ Have you ever used a helmet before } & No & 7,600 & 40.2 & 5,925 & 52.6 \\
\hline & Yes & 11,290 & 59.8 & 2,395 & 31.7 \\
\hline \multirow[t]{2}{*}{ Perceived danger of not using a helmet } & No & 4,720 & 25.0 & 2,008 & 42.7 \\
\hline & Yes & 14,175 & 75.0 & 6,316 & 44.7 \\
\hline \multirow[t]{3}{*}{ Aware of danger of not using a helmet } & Low & 840 & 4.4 & 425 & 50.7 \\
\hline & Moderate & 7,525 & 39.8 & 3,328 & 44.4 \\
\hline & High & 10,544 & 55.8 & 4,580 & 43.6 \\
\hline \multirow{4}{*}{$\begin{array}{l}\text { Perceived risk about being caught by the } \\
\text { police because of not using a helmet }\end{array}$} & High risk & 7,788 & 41.3 & 3,602 & 46.4 \\
\hline & Moderate risk & 7,411 & 39.3 & 3,271 & 44.3 \\
\hline & Low risk & 2,078 & 11.0 & 855 & 41.3 \\
\hline & No risk & 1,595 & 8.5 & 584 & 36.7 \\
\hline \multirow{2}{*}{$\begin{array}{l}\text { Ever been caught by police because of not } \\
\text { using a helmet }\end{array}$} & No & 8,918 & 52.8 & 3,839 & 38.6 \\
\hline & Yes & 9,983 & 47.2 & 4,483 & 50.4 \\
\hline \multicolumn{6}{|c|}{$\begin{array}{l}\text { Exposure to road safety awareness (RSA) campaign } \\
\end{array}$} \\
\hline \multirow[t]{2}{*}{ Heard advertising campaign on RSA } & No & 3,066 & 16.1 & 1,428 & 46.9 \\
\hline & Yes & 15,926 & 83.9 & 6,938 & 43.7 \\
\hline \multirow[t]{4}{*}{ RTI campaign on radio or TV } & Never & 2,476 & 13.2 & 1,198 & 48.5 \\
\hline & Not often & 10,253 & 54.5 & 4,391 & 43.0 \\
\hline & Frequently & 5,493 & 29.2 & 2,409 & 44.0 \\
\hline & Not sure & 587 & 3.1 & 272 & 46.4 \\
\hline \multirow[t]{3}{*}{ Talking to others about RSA in the media } & Never & 7,729 & 40.8 & 3,789 & 49.2 \\
\hline & Ever & 7,600 & 40.1 & 3,031 & 40.0 \\
\hline & Not sure & 3,620 & 19.1 & 1,533 & 42.6 \\
\hline \multirow[t]{4}{*}{ How feel about RSA media } & Not like & 1,119 & 5.9 & 560 & 50.0 \\
\hline & Like a little bit & 11,676 & 61.7 & 5,148 & 44.3 \\
\hline & Like very & 5,173 & 27.3 & 2,205 & 42.7 \\
\hline & $\begin{array}{l}\text { much } \\
\text { Not sure }\end{array}$ & 955 & 5.0 & 433 & 45.4 \\
\hline \multirow[t]{4}{*}{ Follows the TV news report on RSA statistics } & Never & 2,614 & 13.8 & 1,256 & 48.2 \\
\hline & Not often & 9,841 & 52.0 & 4,415 & 45.0 \\
\hline & Frequently & 5,552 & 29.3 & 2,244 & 40.6 \\
\hline & Not sure & 912 & 4.8 & 436 & 48.2 \\
\hline
\end{tabular}


3.3. Association between Non-Helmet Use and Demographics, Experiences, Attitudes and RSA Campaign Exposure

In multivariable analysis, it was found that the highest proportion of non-helmet use among motorcyclists was in the age group 15 to 17 years old and in riders from the northern region in Thailand. Motorcyclists who were having a passenger were significantly more often not using helmet than those who had no passenger (see Table 3).

Table 3. Results: Association between non-helmet use and demographics, environmental factors, helmet use experiences and attitudes and RSA campaign exposure (during Songkran festival) by the logistic regressions.

\begin{tabular}{|c|c|c|}
\hline & & Non-helmet use-rider \\
\hline & & Adjusted Odds Ratio $^{a}$ \\
\hline Demographics & Gender & \\
\hline & Female & 1.00 (Reference) \\
\hline & Male & $1.00(0.93-1.07)$ \\
\hline & Age & \\
\hline & $<15$ years old & 1.00 \\
\hline & $15-17$ & $1.45(1.16-1.83)^{* * *}$ \\
\hline & $18-25$ & $0.95(0.77-1.18)$ \\
\hline & $26-59$ & $0.46(0.37-0.57)^{* * *}$ \\
\hline & 60 or more & $0.33(0.21-0.52)^{* * *}$ \\
\hline & Region & \\
\hline & North & 1.00 \\
\hline & Central & $0.40(0.36-0.44)^{* * *}$ \\
\hline & Northeast & $0.34(0.31-0.37)^{* * *}$ \\
\hline & South & $0.19(0.18-0.21)^{* * *}$ \\
\hline Environmental & Motorcycle up to 110 cc vs. more than 110 cc & $0.92(0.87-1.14)$ \\
\hline factors & Having a passenger versus none & $1.62(1.52-1.73)^{* * *}$ \\
\hline & Day of Songkran festival & \\
\hline & 13 April 2007 & 1.00 \\
\hline & 14 April & $0.93(0.85-1.01)$ \\
\hline & 15 April & $1.03(0.94-1.12)$ \\
\hline & 16 April 2007 & $0.70(0.64-0.77)^{* * *}$ \\
\hline & Time of the day & \\
\hline & 07:00-09:00 & 1.00 \\
\hline & 13:00-15:00 & $1.15(1.06-1.25)^{* * *}$ \\
\hline & 17:00-19:00 & $1.16(1.07-1.26)^{* * *}$ \\
\hline & 22:00-24:00 & $1.27(1.13-1.43)^{* * *}$ \\
\hline & Type of road & \\
\hline & Main road in town & 1.00 \\
\hline & Roads out of town & $1.20(1.11-1.30)^{* * *}$ \\
\hline & Highway & $1.10(1.03-1.21)^{*}$ \\
\hline
\end{tabular}


Table 3. Cont.

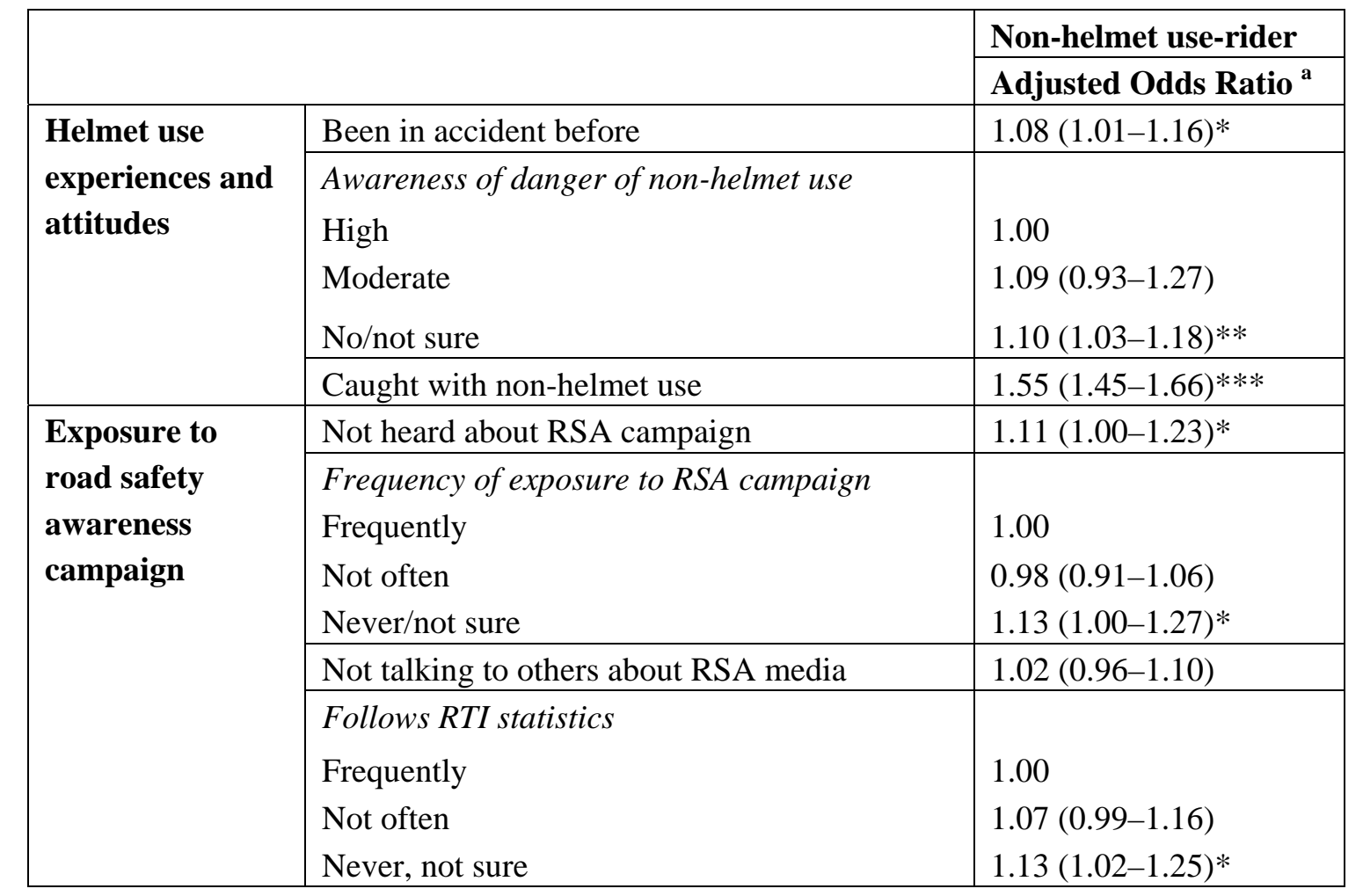

${ }^{a}$ Hosmer \& Lemeshow Chi-square $=21.70, P=0.005$; Log likelihood: 21,273.24, Nagelkerke $\mathrm{R}^{2}: 0.19 ;{ }^{* * *} P<0.001 ;{ }^{* *} P<0.01 ; * P<0.05$; number of observations of this regression $=18,850$.

Non-helmet use was found to be more frequent earlier during the Songkran festival, later during the day, on roads out of town and on highways. Respondents who had been in an accident before, had low awareness of the danger of non-helmet use and having been caught for non-helmet use were more likely to not wear a helmet. Motorcyclists who recalled a lower exposure to road safety awareness campaign (not heard of RSA, never exposed to RSA and did not follow RTI statistics) were more likely not to wear a helmet compared to those who recalled a higher exposure to road safety awareness campaign.

\subsection{Discussion}

This study among a large sample of motorcyclists in Thailand found that $44.2 \%$ of the motorcycle riders and $72.5 \%$ of motorcycle passengers had not been wearing a helmet, which is similar to a survey of 2007 in Thailand, with $46 \%$ and $69.1 \%$ non-helmet use among motorcyclists and passengers, respectively [9]. Similar high rates of non-helmet use among motorcycle riders and passengers have been found in some other studies in low and middle income countries [8,10,11], and even lower rates of helmet use was found in countries such as India [12], Iran [13], Nigeria [14] and Vietnam [15]. These findings highlight that safety helmets continue to be underused by a large segment of motorcyclists in low and middle income countries. Efforts to identify solutions to increase helmet use in these parts of the world need to continue. The study found in agreement with other studies [19] that having been in an accident before, low awareness of danger of non-helmet use [13] and having a passenger [30] were associated with unhelmeted motorcycle riding. Moreover, having been caught for non-helmet use was also found to be associated with non-helmet use in this study. These findings 
suggest a pattern of persistent high risk behaviour among persons previously in an accident and having been caught for non-helmet use [31]. The relatively high prevalence of riding unhelmeted later in the day or at night among motorcyclists in this study is perhaps attributable to insufficient law enforcement at night. In a questionnaire survey in Indonesia, respondents reported that they were less likely to wear helmets at night when there were no police officers on the road [32]. Further, the study found in line with some other studies that demographic characteristics (younger people $[10,15,16]$ and being a passenger [11]) were associated with non-helmet use. Environmental characteristics (earlier during the Songkran festival, later during the day or at night, coming from the Northern region, on roads out of town and on highways) [10,11,22] were also associated with unhelmeted motorcycle riding. Younger people in their teens tend to partake in high-risk behaviours such as non-helmet use [33]. Reasons for the environmental differences found may be that the enforcement by police could be greater on national highways and principal arteries and during work days and rush hour [10]. Differences may also be due to lower vehicle speeds in lateral streets or shorter driving distances, which have previously been found to be associated with low helmet use [34]. In addition, earlier during the Songkran festival and coming from the Northern region were found to be associated with lower helmet use. It is possible that helmet use increased towards the end of the Songkran festival since motorcyclists faced stricter helmet use law reinforcement. The finding of low helmet use in the Northern region in Thailand was confirmed by a study by Pitaktong et al. [19] who found $72.7 \%$ of male and $64.4 \%$ of female students reported non-helmet use. The results derived from studying these factors provide documentation for the priorities for campaigns or measures targeting extensive helmet use by motorcycle riders.

In contrast to other studies, this study did not find any association between gender $[10,11,15]$ and lack of intention to use a helmet [13] and non-helmet use. Importantly, recalling a lower exposure to RSA campaign was found in this study to be weakly associated to non-helmet use among motorcyclists. This finding may indicate that the RSA campaign may have some positive effect on reducing non-helmet use among motorcycle riders during the Songkran festival. Phillips et al. [35] found from meta-analysis (67 studies) the weighted average effect of road safety campaigns was a 9\% reduction in accidents.

\subsection{Study Limitations}

Caution should be taken when interpreting the results of this study because of certain limitations. Since the sampling procedure was not truly random, this may be a limitation of the study. As this is a cross-sectional study, causality between the compared variables cannot be concluded. A further limitation is that some variables were assessed by self-report, and desirable responses may have been given. Other examples of limitations include that substance use (alcohol and illicit drugs) [36-38], unfavorable weather conditions [39] and after midnight ride, experience/duration after having riding license [40] and safety riding training [41] were not assessed. Finally, the assessment of the exposure to the RSA campaign and effects on helmet use were not assessed in a controlled design, which limits the findings effects. Further, evaluating interventions by assessing the correlation between behaviours and the recall of having seen an advertisement is a finding with a high risk of confounding, as those who comply with the behaviour encouraged/enforced might be more likely to remember it (or accept being reminded about it). 


\section{Conclusions}

Rates of non-helmet use by Thai motorcycle riders and passengers during Songkran festival seemed to be high. It appears that the road safety awareness campaign may have a slight positive effect on reducing non-helmet use among motorcycle riders during the Songkran festival. The presented information concerning different peaks of unhelmeted motorcyclists will be helpful in devising specific countermeasures against such risky behaviour.

\section{Acknowledgement}

The study was funded by the Thai Health Promotion Foundation/Department of Disaster Prevention and Mitigation, Ministry of Interior, Thailand. The funding number was MT0603/2551, duration was April-October, 2007.

\section{Conflict of Interest}

The authors declare that they have no competing interests.

\section{References and Notes}

1. World Health Organization (WHO). Reference. In Global Status Report on Road Safety: Time for Action. World Health Organization: Geneva, Switzerland, 2009.

2. Burden of Disease and Injuries in Thailand. Available online: http://www.thaibod.net/documents/ DISEASEBURDEN1999.pdf (accessed on 10 April 2012).

3. Hyder, A.A.; Waters, H.; Phillips, T.; Rehwinkel, J. Exploring the economics of motorcycle helmet laws-Implications for low and middle-income countries. Asia Pac. J. Public Health 2007, 19, 16-22.

4. Stephan, K.; Kelly, M.; McClure, R.; Seubsman, S.A.; Yiengprugsawan, V.; Bain, C.; Sleigh, A.; Thai Cohort Study Team. Distribution of transport injury and related risk behaviours in a large national cohort of Thai adults. Accid Anal Prev. 2011, 43, 1062-1067.

5. Swaddiwudhipong, W.; Nguntra, P.; Mahasakpan, P.; Koonchote, S.; Tantriratna, G. Epidemiologic characteristics of drivers, vehicles, pedestrians and road environments involved in road traffic injuries in rural Thailand. Southeast Asian J. Trop. Med. Public Health 1994, 25 , 37-44.

6. Suriyawongpaisal, P.; Kanchanasut, S. Road traffic injuries in Thailand: Trends, selected underlying determinants and status of intervention. Injury Control Saf. Promot. 2003, 10, 95-104.

7. Woratanarat, P.; Ingsathit, A.; Suriyawongpaisal, P.; Rattanasiri, S.; Chatchaipun, P.; Wattayakorn, K.; Anukarahanonta, T. Alcohol, illicit and non-illicit psychoactive drug use and road traffic injury in Thailand: A case-control study. Accid. Anal. Prevent. 2009, 41, 651-657.

8. Ruangkanchanasetr, S.; Plitponkarnpim, A.; Hetrakul, P.; Kongsakon, R. Youth risk behavior survey: Bangkok, Thailand. J. Adolesc. Health 2005, 36, 227-235.

9. Status Paper on Road Safety 2010 (Thailand). Available online: http://www.unescap.org/ ttdw/common/Meetings/TIS/EGM-Roadsafety-2011/Status/Countries/Thailand-2010-Status.pdf (accessed on 16 January 2012). 
10. Li, L.P.; Li, G.L.; Cai, Q.E.; Zhang, A.L.; Lo, S.K. Improper motorcycle helmet use in provincial areas of a developing country. Accid. Anal. Prevent. 2008, 40, 1937-1942.

11. Yu, X.Q.; Liang, K.; Rebecca, I.; Wei, D.; Teresa, S. Prevalence rates of helmet use among motorcycle riders in a developed region in China. Accid. Anal. Prevent. 2011, 43, 214-219.

12. Sreedharan, J.; Muttappillymyalil, J.; Divakaran, B.; Haran, J.C. Determinants of safety helmet use among motorcyclists in Kerala, India. J. Inj. Violence Res. 2010, 2, 49-54.

13. Ali, M.; Saeedmj, M.M.; Ali, M.M.; Haidar, N. Determinants of helmet use behaviour among employed motorcycle riders in Yazd, Iran based on theory of planned behaviour. Injury 2011, 42, 864-869.

14. Oginni, F.O.; Ugboko, V.I.; Adewole, R.A. Knowledge, attitude, and practice of Nigerian commercial motorcyclists in the use of crash helmet and other safety measures. Traffic Injury Prevent. 2007, 8, 137-141.

15. Hung, D.V.; Stevenson, M.R.; Ivers, R.Q. Prevalence of helmet use among motorcycle riders in Vietnam. Inj. Prev. 2006, 12, 409-413.

16. Nakahara, S.; Chadbunchachai, W.; Ichikawa, M.; Tipsuntornsak, N.; Wakai, S. Temporal distribution of motorcyclist injuries and risk of fatalities in relation to age, helmet use, and riding while intoxicated in Khon Kaen, Thailand. Accid. Anal. Prevent. 2005, 37, 833-842.

17. Ichikawa, M.; Chadbunchachai, W.; Marui, E. Effect of the helmet act for motorcyclists in Thailand. Accid. Anal. Prevent. 2003, 35, 183-189.

18. Kanitpong, K.; Boontob, N.; Tanaboriboon, Y. Helmet use and effectiveness in reducing the severity of head injuries in Thailand. Transport. Res. Record: J. Transport. Res. Board 2008, doi: 10.3141/2048-09.

19. Pitaktong, U.; Manopaiboon, C.; Kilmarx, P.H.; Jeeyapant, S.; Jenkins, R.; Tappero, J.; Uthaivoravit, W.; van Griensven, F. Motorcycle helmet use and related risk behaviors among adolescents and young adults in Northern Thailand. Southeast Asian J. Trop. Med. Public Health 2004, 35, 232-241.

20. Liu, B.C.; Ivers, R.; Norton, R.; Boufous, S.; Blows, S.; Lo, S.K. Helmets for preventing injury in motorcycle riders. Cochrane Database Syst Rev. 2004, 4, 1-42.

21. Swaddiwudhipong, W.; Boonmak, C.; Nguntra, P.; Mahasapan, P. Effect of motorcycle rider education on changes in risk behaviors and motorcycle-related injuries in rural Thailand. Trop. Med. Int. Health. 1998, 3, 767-770.

22. Ditsuwan, V.; Veerman, J.L.; Bertram, M.; Vos, T. Sobriety checkpoints in Thailand: A review of effectiveness and developments over time. Asia Pac. J. Public Health 2011, doi:10.1177/ 1010539511430851.

23. Suriyawongpaisal, P.; Plitapolkarnpim, A.; Tawonwanchai, A. Application of 0.05 percent legal blood alcohol limits to traffic injury control in Bangkok. J. Med. Assn. Thailand 2002, 85, 496-501.

24. Department of Disaster Prevention and Mitigation, Ministry of Interior. Reference. In Evaluation of Road Traffic Prevention Strategic Plan in the Year 2007; Lampang Bannakit Printing: Lampang, Thailand, 2007.

25. World Health Organization (WHO). Thailand 2005. "Year of Road Safety"-National World Health Day Celebrations. Available online: http://www.who.int/world-health-day/2004/activities/ searo/bangkok/en/index.html (accessed on 12 December 2011). 
26. Iamtrakul, P.; Tanaboriboon, Y. Analysis of motorcycle accidents in developing countries: A case study of Khon Kaen, Thailand. J. Eastern Asian Soc. Transp. Stud. 2003, 5, 147-162.

27. Ponboon, S.; Tanaboriboon, Y. Development of road accident reporting computerized system in Thailand. J. Eastern Asian Soc. Transp. Stud. 2005, 6, 3453-3466.

28. Songyoo, R. Traffic accidents during Songkran Festival in Nongbualumpoo Province: An epidemiological study. Khon Kaen Med. J. 2002, 26, 28-40.

29. Saipan, S.; Boonpaisarn, B.; Moongmai, V.; Maliwan, N.; Saipan, P.; Suwaratchai, P. Road safety control during long holidays in Ubonratchathani Province, Thailand. Injury Prevent. 2010, 16, A203-A204.

30. Ackaah, W.; Afukaar, F.K. Prevalence of helmet use among motorcycle users in Tamale Metropolis, Ghana: An observational study. Traffic Injury Prevent. 2010, 11, 522-525.

31. Mangus, R.S.; Simons, C.J.; Jacobson, L.E.; Streib, E.W.; Gomez, G.A. Current helmet and protective equipment usage among previously injured ATV and motorcycle riders. Injury Prevent. 2004, 10, 56-58.

32. Conrad, P.B.Y.; Lamsudin, R.; Kasniyah, N.; Costello, C. Helmets, injuries and cultural definitions: Motorcycle injury in urban Indonesia. Accid. Anal. Prevent. 1996, 28, 193-200.

33. Williams, A.F. Teenage drivers: Patterns of risk. J. Safety Res. 2003, 34, 5-15.

34. Kulanthayan, S.; Umar, R.S.; Hariza, H.A.; Nasir, M.T. Modeling of compliance behavior of motorcyclists to proper usage of safety helmets in Malaysia. Crash Prevent. Injury Control 2001, 2, 239-246.

35. Phillips, R.O.; Ulleberg, P.; Vaa, T. Meta-analysis of the effect of road safety campaigns on accidents. Accid. Anal. Prevent. 2011, 43, 1204-1218.

36. Sirathranont, J.; Kasantikul, V. Mortality and injury from motorcycle collisions in Phetchaburi Province. J. Med. Assn. Thailand 2003, 86, 97-102.

37. Ingsathit, A.; Woratanarat, P.; Anukarahanonta, T.; Rattanasiri, S.; Chatchaipun, P.; Wattayakorn, K.; Lim, S.; Suriyawongpaisal, P. Prevalence of psychoactive drug use among drivers in Thailand: A roadside survey. Accid. Anal. Prevent. 2009, 41, 474-478.

38. Lin, M.R.; Kraus, J.F. A review of risk factors and patterns of motorcycle injuries. Accid. Anal. Prevent. 2009, 41, 710-722.

39. Ledesma, R.D.; Peltzer, R.I. Helmet use among motorcyclists: Observational study in the city of Mar del Plata, Argentina. Revista de Saúde Pública 2008, 42, 143-145.

40. Skalkidou, A.; Petridou, E.; Papadopoulos, F.C.; Dessypris, N.; Trichopoulos, D. Factors affecting motorcycle helmet use in the population of Greater Athens, Greece. Injury Prevent. 1999, 5, 264-267.

41. Ranney, M.L.; Mello, M.J.; Baird, J.B.; Chai, P.R.; Clark, M.A. Correlates of motorcycle helmet use among recent graduates of a motorcycle training course. Accid. Anal. Prevent. 2010, 42, 2057-2062.

(C) 2012 by the authors; licensee MDPI, Basel, Switzerland. This article is an open access article distributed under the terms and conditions of the Creative Commons Attribution license (http://creativecommons.org/licenses/by/3.0/). 